\title{
RANCANG BANGUN ALAT PERAGA SISTEM OILY WATER SEPARATOR DI KAPAL KM. DOROLONDA
}

\author{
Iqbal Helmi M. ${ }^{1 *}$, Amad Narto ${ }^{1}$, Mashudi Rofik ${ }^{1}$ \\ ${ }^{1}$ Program Studi Teknika Politeknik Ilmu Pelayaran Semarang \\ J1. Singosari Raya No2A, Wonodri, Semarang \\ *Email: I.marsa97@gmail.com
}

\begin{abstract}
Abstrak
Pada era modern di dunia kemaritiman ini proses pembelajaran terkait permesinan kapal sangat diperlukan dan sangat penting untuk dikuasai peserta didik. Sehingga banyak digunakan metode pembelajaran yang efektif salah satunya adalah metode pembelajaran dengan menggunakan alat peraga permesinan diatas kapal, maka dari itu penelitian ini bertujuan untuk mengetahui bagaimana cara membuat alat peraga dan untuk mengetahui prinsip kerja dari alat peraga serta untuk mengetahui manfaat yang didapatkan dari alat peraga. Jenis alat peraga sitem oily water separator di atas kapal. Metode yang digunakan yaitu Research and Development, merupakan proses atau langkah-langkah untuk mengembangkan suatu produk yang sudah ada, baik itu perangkat keras maupun perangkat lunak. Model dalam penelitian pengembangan ini adalah model procedural yaitu menggariskan pada langkah-langkah pembuatan yang terpapar secara urut dan bertahap dari proses awal hingga akhir.
\end{abstract}

Kata kunci: Alat peraga, Oily Water Separator, modul elektronika, Timmer Delay Relay

\section{PENDAHULUAN}

Oily Water Separator (OWS) adalah permesinan bantu atau pesawat bantu diatas kapal yang menyaring dan memisahkan air got yang mengandung minyak, sampai pemisahannya mencapai $15 \mathrm{ppm}$. Bila konsentrasi air got menunjukan $15 \mathrm{ppm}$ maka air akan dibuang kelaut namun bila air got melebihi dari batas $15 \mathrm{ppm}$ maka akan ditampung di sludge tank. Berdasarkan pada penjelasan diatas, pada saat penulis melaksanakan praktek laut di KM DOROLONDA tepatnya pada tanggal 04 September 2018 saat kapal berlayar dari Ternate menuju ke Namlea Indonesia mengalami masalah pada oily water separator (OWS) dimana oily water separator tidak dapat bekerja secara optimal pada saat dilakukan proses pengoperasian akan tetapi ditengah proses pengoperasian kandungan minyak dalam air buangan tinggi yaitu lebih dari 15 ppm dan oil content meter memberikan sinyal alarm secara terus menerus. Dengan mencermati permasalahan di atas, maka saya selaku peneliti memutuskan untuk merancang bangun permesinan bantu oily water separator (OWS) pada kapal.
Berdasarkan pada latar belakang diatas maka peneliti mengambil rumusan permasalahan sebagai berikut: Bagaimana cara membuat rancang bangun oily water separator (OWS). (2) Bagaimana prinsip kerja dari rancang bangun oily water separator (OWS). (3) Apa manfaat dari rancang bangun oily water separator (OWS).

\section{LANDASAN TEORI}

Pengertian perancangan menurut Satzinger, Jackson, Burd (2010), perancangan sistem adalah proses menentukan secara detail bagaimana komponen-komponen sistem informasi secara fisik dapat diimplementasikan dan memenuhi persyaratan pengguna sistem. Menurut O’Brien dan Marakas (2010), perancangan sistem adalah proses merancang sistem dari model yang ada dan dimodifikasi sampai mempresentasikan apa yang dapat dilakukan oleh sistem baru. Berdasarkan pengertian mengenai perancangan yang telah dipaparkan di atas, maka dapat diperoleh kesimpulan bahwa perancangan sistem adalah proses kegiatan mendesain sesuatu model untuk 
menghasilkan karya yang bermanfaat bagi pemakai sistem tersebut dan dapat mencapai hasil yang memuaskan bagi pemakai sistem dari model yang dirancang.

\section{Pengertian Alat Peraga}

Alat peraga adalah suatu alat yang dipakai untuk membantu proses belajar mengajar yang berperan besar sebagai pendukung kegiatan belajar mengajar yang berperan besar sebagai pendukung kegiatan belajar mengajar yang dilakukan oleh pengajar atau guru. Alat peraga menurut Anderson adalah segala sesuatu yang dapat digunakan untuk membantu peserta didik memperkuat informasi atau keterampilan baru yang diperoleh (Muhammad Yaumi, 2018).

Menurut terminologi kata media berasal dari bahasa latin "medium" yang artinya perantara, media mula-mula dikenal dengan alat peraga. Media belajar adalah segala sesuatu yang dapat digunakan untuk menyalurkan pesan (bahan pelajaran), sehingga dapat merangsang perhatian, minat, pikiran dan perasaan pembelajar dalam kegiatan belajar untuk mencapai tujuan pembelajaran tertentu (Prof. Dr. H. M. Rudy Sumiharsono, MM., 2017).

Menurut Siti Adha dkk, (2014), alat peraga adalah satu diantara beberapa cara untuk mengaktifkan siswa berinteraksi dengan materi ajar diperlukan suatu alat bantu yang disebut alat peraga. Dalam interaksi ini siswa akan membentuk komunitas yang memungkinkan mereka mencintai proses pembelajaran. Pemanfaatan alat peraga dalam pembelajaran matematika sangat diperlukan karena dengan menggunakan alat peraga siswa berpikir abstrak sehingga penggunaan alat peraga sangat diperlukan dalam menjelaskan dan menanamkan konsep pembelajaran matematika

Azhar Arsyad mengatakan, Alat peraga adalah media alat bantu pembelajaran dengan segala macam benda yang digunakan untuk memperagakan materi pelajaran (Azhar Arsyad, 2013).
Menurut Agus Suharjana dkk, (2010) dalam Sulaiman (2015) menyatakan bahwa alat peraga merupakan media pembelajaran yang mengandung atau membawakan ciridan konsep uang dipelajari

Berdasarkan uraian diatas, penulis menyimpulkan alat peraga adalah alat bantu untuk pembelajaran yang berupa segala macam benda yang dirancang digunakan dan dapat untuk memperagakan materi suatu penunjang pembelajaran dan memiliki konsep sama dengan materi pembelajaran yang dipelajari, serta memiliki ciri-ciri dari konsep yang dipelajari

\section{OilyWater Seperator}

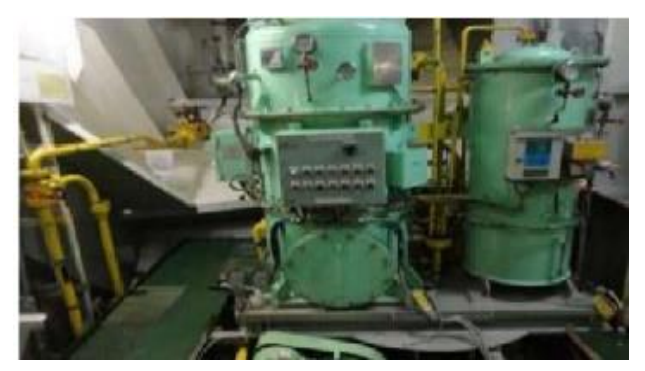

\section{Gambar 1. Oily water separator}

Oily water separator adalah pesawat bantu yang dipakai di atas kapal untuk memisahkan air got di kamar mesin dari campuran minyak, tumpahan, minyak kotor, dari limbah operasi separator minyak lumas, separator bahan bakar dan kebocorankebocoran minyak lumas dari pipa-pipa, dari bodi, mesin induk, juga dari mesin-mesin bantu yang bercampur dengan air yang tertampung di got kamar mesin. Dengan demikian air yang di buang adalah air yang bersih yang memenuhi persyaratan 15 (PPM) sesuai (MARPOL 1973 protokol 1978).

Oily water separator merupakan suatu alat yang digunakan untuk memisahkan antara air dengan minyak yang telah melalui proses pemisahan didalam pesawat oily water separator dengan menggerakan system filterisasi. Yang nantinya hasil dari pemisahan akan dibuang ke laut, dan hasil pembuangan harus berupa air yang bersih tidak mengandung minyak lebih dari 15 
ppm, proses pembuangan ini dengan menggunakan pompa air got yang akan menghisap air got dari bilge tank / bilge wall menuju ke tangki pemisahan, pemisahan ini dengan menggunakan system grafity dan filterisasi sehingga tercegah pencemaran air laut oleh minyak.

Pengertian oily water separator adalah salah satu pesawat yang masuk dalam critical machinery, sehingga OWS diwajibkan ada pada setiap kapal tanpa terkecuali. Oily water separator adalah suatu alat yang digunakan untuk memisahkan antara air dengan minyak yang melalui proses pemisahan di dalam pesawat oil water separator dengan menggunakan sistem filterisasi (Taylor D.A, 2003). Yang nantinya hasil dari pemisahan akan dibuang ke laut. Dan hasil pembuangan harus berupa air yang bersih tidak mengandung minyak lebih dari $15 \mathrm{ppm}$, proses pembuangan ini dengan menggunakan pompa air got (bilge pump) yang akan menghisap air got dari bilge tank / bilge wall menuju ke tangki pemisahan pada oil water separator , pemisahan ini dengan menggunakan sistem gravitasi dan filterisasi. Di dalam oil water separator terdapat 2 bagian filter, yaitu filter kasar (Demister) dan filter halus (Coalesscer).

Setelah terjadi penyaringan akan menghasilkan 10 perbedaan berat jenis antara air dan minyak, yang mana minyak terdapat pada bagian atas dan air pada bagian bawah. Air yang terdapat di bagian bawah selanjutnya akan menuju ke ODM (Oil Discharge Monitoring). Pada ODM akan dimonitor kadar minyak pada air yang telah melalui penyaringan pada oil water separator. Apabila air bersih dari kadar minyak kurang dari 15 ppm maka akan dibuang ke over board tetapi bila terdapat air dengan kadar minyak melebihi 15 ppm maka ODM akan merespon dan menggerakkan solenoid valve untuk menutup outlet yang menuju ke overboard dan menggantinya dengan membuka outlet yang menuju kembali oil water separator dan akan berjalan seperti itu secara terus menerus hingga kadar minyak pada air buangan tidak melebihi 15 ppm. Sehingga pencemaran air laut oleh minyak dapat dicegah. Pentingnya pesawat ini ada pada setiap kapal guna memenuhi persyaratan atau peraturan internasional mengenai pencegahan pencemaran air laut atau polusi yang akan membahayakan lingkungan laut. Pada dasarnya di dalam suatu pesawat oil water separator akan terdapat berbagai macam permasalahan yang akan terjadi yang disebabkan karena kesalahan para masinis dalam pengoperasiannya dan kurangnya perawatan pada pesawat Oil Water Separator. Hal ini dapat dan bisa menjadi mengakibatkan menurunnya kemampuan kinerja dari pesawat oil water separator sehingga akan mempengaruhi hasil air buangan yang kurang maksimal. Oleh sebab itu agar pesawat dapat bekerja dengan normal maka para masinis diharuskan dapat mengerti cara-cara pengoperasiannya dan melakukan perawatan yang telah dijadwalkan sesuai dengan buku manual, sehingga pesawat dapat bekerja dengan normal

\section{METODE}

Metode Penelitian, Penelti menggunakan metode Research and Development. Metode ini digunakan peneliti untuk penelitian serta mengembangkan suatu produk yang diawali dari analisa, desain, perancangan, pengodean, serta pengujian. Reseacrh and Development $(R n D)$ atau dalam bahasa indonesianya penelitian dan pengembangan adalah proses mengembangkan suatu produk dan akan menghasilkan sauatu produk baru atau menyempurnakan produk yang sudah ada sebelumnya. Dalam hal ini tidak selalu perangkat keras atau hardware yang dapat dikembangkan, tetapi dapat juga perangkat lunak atau software.

\section{Desain Penelitian}

Desain penelitian merupakan tahapan yang digunakan dalam penelitian, dalam penelitian ini peneliti membuat 
rancang bangun atau membuat alat peraga sebagai bentuk perangkat berukuran kecil dari objek yang dikembangkan. Penulis akan membuat desain penelitian dalam bentuk diagram tahapan

\section{Prosedur Penelitian}

Prosedur penelitian merupakan langkah-langkah yang dilakukan peneliti secara teratur untuk mencapai tujuan penelitian (Fitrah, 2017).

\section{Tahap Analisis}

Analisis merupakan cara mengamati serta mempelajari tentang hal untuk tujuan tertentu, misalnya adalah untuk mengembangkan suatu alat atau produk tertentu. Jadi umumnya tahap ini adalah tahap awal yang digunakan peneliti (Timotius, 2017).

Pada tahap ini peneliti harus mengetahui dan mempelajari alat yang akan dirancang, supaya dapat mempersiapkan jumlah bahan, jenis bahan dan alat yang akan digunakan. Tahap awal ini peneliti akan mempersiapkan untuk proses selanjutnya yaitu membuat sket atau desain produk yang akan dirancang.

\section{Desain Perancangan Alat}

tentunya perancang akan mempertimbangkan banyak hal untuk membuat hasil yang maksimal, salah satunya adalah bentuk dari suatu alat atau produk yang akan dibuat, jadi perancang harus melalui tahap desain. Tahap ini perancang membuat dua desain perancangan, yaitu perancangan mekanik dan perancangan elektronika.

Desain perancangan mekanik peneliti membuat sket ows dengan dua tabung yang akan dibuat, memperhitungkan ukuran dan bentuknya. Sedangkan desain perancangan elektronika perancang membuat blok diagram dan kode pemrograman.

\section{Tahap Pembuatan Alat}

Dalam penelitian ini, peneliti akan membuat alat peraga yang dibuat sendiri, maka perancang membuat bagian-bagian dari alat peraga tersebut dengan ukuran yang sudah didesain pada tahap sebelumnya.

\section{Tahap Perancangan}

Setelah bagian perbagian sudah dibuat dengan penuh perhitungan, masuk tahap selanjutnya yaitu perancangan. Karena alat peraga model pengembangan ini memadukan pemisah dengan teknologi pengodean arduino uno sebagai mikrokontroler, tahap ini dibagi menjadi dua bagian.

\section{Perancangan Mekanik}

Bagian-bagian dari alat peraga yang selesai dibuat akan dirancang atau dirakit sesuai desain yang sudah dibuat dan nantinya akan dipadukan dengan sistem kontrol elektronika.

\section{Perancangan Elektronika}

Perancangan elektronika merupakan hal penting dalam penelitian ini, karena peneliti mengembangkan pemisah dengan teknologi pengodean arduino uno sebagai mikrokontroler sebagai sistem prtintah. Tahap ini perancang meletakkan komponen elektronika sesuai desain yang telah dibuat, dan menghubungkan antar komponen sesuai diagram blok sesai desain.

\section{Tahap Pemrograman}

Alat peraga model pengembangan yang sudah selesai dirancang belum bisa berfungsi dengan baik sebelum dilakukan pemrogaman. Maka perancang akan memrogram mikrokontroler sesuai keinginan atau harapan perancang, memakai aplikasi arduino uno mikrokontroler tersebut. Perancangan ows ini menggunakan ardino uno sebagai mikrokontroler. Arduino memiliki apllikasi khusus untuk pemrogrmannya, dan menggunakan bahasa pemrograman yang lebih mudah dibandingkan dengan mikrokontroler lain, 
oleh sebab itu dalam perancangan ini menggunakan arduino sebagai mikrokontroler karena mudah digunakan.

\section{Tahap Pengujian Alat}

Setelah alat peraga sudah selesai dirancang dan diprogram, maka alat tesebut harus diuji untuk memastikan alat tersebut berfungsi sesuai dengan harapan. Karena alat yang dikembangkan adalah sebuah alat pemisah antar air dan minyak, maka perancang harus menguji dengan teliti. Jika alat peraga beroperasi atau ppm tidak sesuai harapan maka akan dilakukan perbaikan.

\section{Tahap Evaluasi}

Evaluasi adalah dimana perancang menyimpulkan dari hasil pengujian alat peraga yang telah dibuat. Jika saat diuji han hasilnya tidak sesuai harapan maka dibutuhkan perbaikan, baik bagian rancangan mekanik maupun bagian pemrograman atau elektronika. Evaluasi adalah tahap akhir dimana perancang menilai alat yang selesai dibuat apakah layak atau tidak untuk didemonstrasikan.

\section{Alat dan Bahan}

Sebagai hal yang harus ada dalam perancangan alat peraga ini adalah alat dan bahan, maka alat dan bahan harus dipersiapkan dengan baik, dengan banyak pertimbangan seperti jenis, fungsi dan jumlah yang diperlukan.

Tabel 1. Daftar nama alat

\begin{tabular}{|l|c|l|}
\hline & $\begin{array}{c}\text { Nama } \\
\text { Alat }\end{array}$ & \multicolumn{1}{|c|}{ Fungsi } \\
\hline Mesin bor & 1 unit & $\begin{array}{l}\text { Untuk } \\
\text { melubangi pipa } \\
\text { dan kayu } \\
\text { landasan }\end{array}$ \\
\hline Solder & 1 unit & $\begin{array}{l}\text { Untuk } \\
\text { melelehkan tenol }\end{array}$ \\
\hline Obeng & 1 unit & $\begin{array}{l}\text { Untuk mengikat } \\
\text { sekrup }\end{array}$ \\
\hline Ppm mater & 1 unit & $\begin{array}{l}\text { Untuk mengukur } \\
\text { ppm }\end{array}$ \\
\hline Spidol & 1 unit & Untuk menandai \\
\hline
\end{tabular}

\begin{tabular}{|l|l|l|}
\hline & & $\begin{array}{l}\text { bahan yang } \\
\text { dikerjakan }\end{array}$ \\
\hline $\begin{array}{l}\text { Gergaji } \\
\text { kayu }\end{array}$ & 1 unit & $\begin{array}{l}\text { Untuk } \\
\text { memotong kayu } \\
\text { pondasi }\end{array}$ \\
\hline Pisau/Cutter & 1 unit & $\begin{array}{l}\text { Untuk } \\
\text { merapikan dan } \\
\text { memotong bahan }\end{array}$ \\
\hline Filter & 1 set & $\begin{array}{l}\text { Untuk menggaris } \\
\text { akrilik dan } \\
\text { mendesain }\end{array}$ \\
\hline Meteran & 1 unit & $\begin{array}{l}\text { Untuk mengukur } \\
\text { bahan }\end{array}$ \\
\hline pompa & 1 unit & $\begin{array}{l}\text { Untuk } \\
\text { memindahkan } \\
\text { cairan }\end{array}$ \\
\hline Laptop & 1 unit & $\begin{array}{l}\text { Untuk } \\
\text { memrogram } \\
\text { mikrokontroler }\end{array}$ \\
\hline
\end{tabular}

Dalam pembuatan alat peraga tentunya membutuhkan banyak jenis bahan dan jumlah tertentu

\section{Tabel 2. Daftar nama bahan}

\begin{tabular}{|l|l|l|}
\hline $\begin{array}{l}\text { Nama } \\
\text { Bahan }\end{array}$ & $\begin{array}{l}\text { Jumla } \\
\mathrm{h}\end{array}$ & \multicolumn{1}{|c|}{ Keterangan } \\
\hline $\begin{array}{l}\text { Papan } \\
\text { kayu }\end{array}$ & $\begin{array}{l}1 \\
\text { lembar }\end{array}$ & 1 x $0,7 \mathrm{~m}$ \\
\hline pompa & 2 unit & $\begin{array}{l}3.5 \mathrm{~L} / \mathrm{min}, \\
\text { DC12V }\end{array}$ \\
\hline Sekrup & 1 pack & $\begin{array}{l}\text { Panjang } 1,5 \\
\text { cm }\end{array}$ \\
\hline $\begin{array}{l}\text { Project } \\
\text { board }\end{array}$ & 1 unit & $\begin{array}{l}\text { Sebagai basis } \\
\text { rangkaian }\end{array}$ \\
\hline $\begin{array}{l}\text { Arduin } \\
\text { o uno } \\
\text { Atmega }\end{array}$ & 1 unit & $\begin{array}{l}\text { Mikrokontrole } \\
\mathrm{r}\end{array}$ \\
\hline $\begin{array}{l}\text { Motor } \\
\text { DC }\end{array}$ & 1 unit & $\begin{array}{l}\text { Penggerak } \\
\text { roller }\end{array}$ \\
\hline Tenol & 1 gulung & $\begin{array}{l}\text { Untuk } \\
\text { menyolder }\end{array}$ \\
\hline $\begin{array}{l}\text { Ppm } \\
\text { meter }\end{array}$ & 1 unit & $\begin{array}{l}\text { 0- } \\
\text { 999ppm/mg/L }\end{array}$ \\
\hline
\end{tabular}

\section{Waktu dan Tempat Penelitian}

Waktu Penelitian

Penelitian model pengembangan ows dilakukan oleh peneliti terhitung mulai tanggal 04-11-2020, dan perancangan selesai pada tanggal 27-01-2021. 


\section{Tempat Penelitian}

Tempat dilaksanakan penelitian ini mulai dari persiapan, desain, pembuatan, perancangan mekanik, perancangan sistem kontrol, pemrogaman dan pengujian alat dikerjakan di rumah

\section{Metode Pengumpulan Data}

Tahapan dimana peneliti mendapatkan data yang diperlukan untuk penelitian. Pengumpulan data dilakukan untuk memperoleh informasi yang dibutuhkan untuk mendukung tercapainya penelitian (Ismail, 2018).

\section{Observasi (Pengamatan)}

Pengumpulan data dengan cara mengamati langsung adalah cara pengambilan data yang menggunakan indra penglihatan. Dengan cara ini peneliti dapat mengevaluasi kekurangan hal yang sedang diamati. Peneliti melakukan pengamatan dalam kehidupan perihal penggunaan ows pada banyak bidang. Tak hanya pada kapal ows juga digunakan pada restoran atau pada hotel besar.

\section{Studi Pustaka}

Metode ini digunakan untuk bahanbahan atau data berupa file, baik itu soft file maupun hard file. Banyak sumber yang dapat dimanfaatkan untuk mengumpulkan data dengan metode ini, seperti buku di perpustakaan, catatan, jurnal ilmiah, data sheet suatu produk. Pada perkembangan zaman seperti sekarang ini, selain sumber yang disebutkan peneliti juga memanfaatkan kecanggihan kemajuan teknologi yaitu $e$ book.

Studi pustaka merupakan hal penting dalam perancangan alat peraga model pengembangan, karena dalam perancangan membutuhkan banyak sumber data. Karena peneliti mengembangkan pemisahan air dengan minyak, maka peneliti membutuhkan data sheet masing-masing komponen yang digunakan. Dengan mempelajari dan memahami data sheet peneliti dapat mengetahui spesifikasi dan kekurangan serta kelebihan masing-masing komponen, sehingga dapat meminimalisir kesalahan penggunaan komponen tersebut

\section{Teknik Analisa Data}

Analisa data adalah proses pemgolahan data yang telah didapatkan menjadi lebih mudah dimengerti dan berguna untuk solusi atau penyelesaian suatu penelitian (Ismail, 2018).

Pada bagian ini peneliti mengolah data yang telah didapatkan pada tahap pengumpulan data, dan menjadi teori yang akan digunakan untuk merancang alat peraga model pengembangan ows. Dalam pengolahan data tentunya tidak semua data yang telah didapatkan bisa digunakan, karena pasti ada beberapa data yang tidak cocok untuk digunakan.

Perancangan model ows ini membutuhkan data yang valid, karena dalam perancangan ini melibatkan komponen elektronika, dan membutuhkan data yang spesifik untuk dapat diaplikasikan pada beberapa komponen. Misalkan pada pemrograman mikrokontroler dibutuhkan kode khusus untuk dapat beroperasi dengan semestinya, jadi tidak semua sumber data dapat digunakan. Tujuan analisis data adalah mendeskripsikan data yang telah dikumpulkan sehinga mudah dipahami untuk digunakan atau penunjang sebuah penelitian.

\section{HASIL DAN PEMBAHASAN \\ Gambaran Umum}

Oily water separator digunakan untuk memisahkan miyak dari air bilga sebelum akhirnya air dipompa ke overboard dan minyak ke shore connection. Pada tank top di kamar mesin, kita sering menemukan air. Air itu biasanya datang dari pompa dan valve packing, kebocoran, tumpahan, air pencuci, dari pengurasan tabung udara, dan dari banyak sumber. Pada akhirnya, oily water separator, polusi, bilga, katup, packing gland, berat jenis, pemisahan, screw pump, marpol, peraturan- peraturan dikumpulkan sebagai air bilga. Oily water 
separator prinsip kerjanya yaitu menggabungkan tetesan kecil minyak di air menjadi tetesan besar. Ketika tetesan minyak ini cukup besar, minyak yang berat jenisnya lebih rendah mengapung naik keatas dan dikumpulkan di atas bejana. Dan sisa airnya yang ada di bagian bawah dan dipompa ke overboard..

\section{Hasil Penelitian}

Hasil penelitian pembuatan rancang bangun model oily water separator dengan menggunakan kontoler berupa system berbasis arduino, menguji sensor-sensor yang digunakan, dan mendapatkan hasil yang beraneka ragam. Peneliti melakukan pengujian terhadap sensor dengan memberi aksi sesuai kriteria sensor, dan mengamati reaksi yang terjadi akibat aksi tersebut.

Manfaat pengujian sensor adalah untuk mengetahui cara kerja komponen tesebut yang akan dimanfaatkan sebagai komponen pendukung, sehingga penelitian dapat tercipta sesuai harapan peneliti.

\section{Pembahasan}

Perancangan alat peraga model oily water separator dengan menggunakan sistem berbais airduino ini dilakukan secara urut pada setiap proses pembuatannya, dan sudah disesuaikan dengan rumusan masalah. Proses pembuatan dilakukan dengan baik dan terperinci untuk mendapatkan hasil yang diharapkan perancang.

\section{Menyiapkan Alat dan Bahan}

Bagian awal dari pembuatan peraga adalah menyiapkan alat dan bahan yang akan digunakan. Alat dan bahan harus disiapkan dengan baik karena hal ini mempengaruhi kelancaran pembuatan alat peraga.

\section{Akrilik}

Akrilik merupakan plastik yang bentuknya menyerupai kaca. Namun, akrilik ternyata mempunyai sifat-sifat yang membuatnya lebih unggul dibandingkan dengan kaca. Salah satu perbedaanya adalah kelenturan yang dimiliki oleh akrilik. Akrilik merupakan bahan yang tidak mudah pecah, ringan, dan juga mudah untuk dipotong, dikikir, dibor, dihaluskan, dikilapkan atau dicat. Akrilik dapat dibentuk secara thermal menjadi berbagai macam bentuk yang rumit. Sifatnya yang tahan pecah juga menjadikan akrilik sebagai material yang ideal untuk dipergunakan pada aplikasi di tempat-tempat di mana pecahnya material akan berakibat fatal, seperti salah satunya pada jendela kapal selam. Selain anti pecah dan tahan terhadap cuaca, akrilik juga tidak akan mengkerut atau berubah warna meskipun terkena paparan sinar matahari dalam jangka waktu yang lama. Hal ini membuat semua produk dari bahan akrilik bisa digunakan di dalam atau di luar ruangan

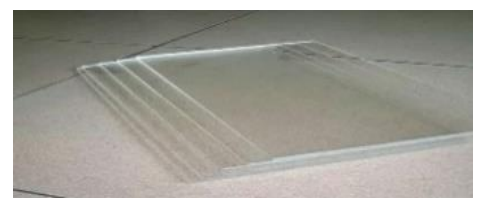

Gambar 2. Akrilik

\section{Pipa Paralon}

Pipa paralon yang berfungsi sebagai tempat penyaringan air kotor. Pipa paralon yang digunakan berukuran, diameter 10,16 $\mathrm{cm}$ sebanyak 2 buah pipa paralon dengan panjang $40 \mathrm{~cm}$ masing- masingnya.

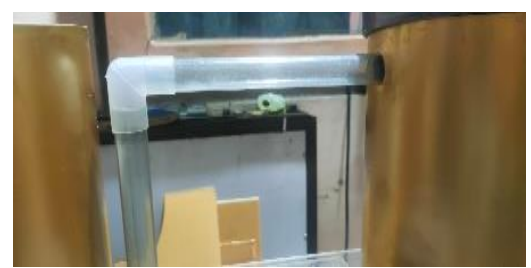

\section{Gambar 3. Pipa Diameter 10,16 cm}

\section{Pipa Paralon dan Sambungan}

Bahan ini menggunakan pipa paralon bening yang sering digunakan oleh akuarium, paralon bening ini berukuran $3 / 8$ in yang biasa dijual di toko akuarium, untuk sambungannya menggunakan knee L yang bisa untuk menyambungkan belokan pipa 


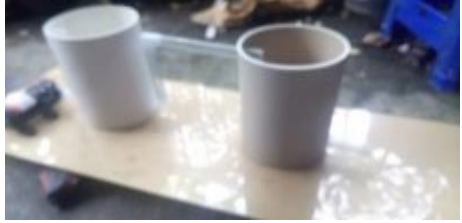

Gambar 4. Pipa Paralon dan Sambungan

\section{Sensor TDS Meter}

Sebuah alat yang digunakan sebagai sensor untuk mengukur seberapa banyaknya ppm pada air yang sudah melewati proses penyaringan untuk diketahui kandungan air setelah mengalami proses penyaringan.

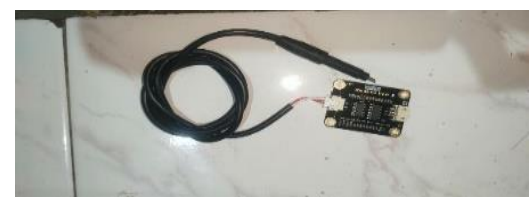

Gambar 5. Sensor TDS Meter

\section{Lem Super}

Perancang menggunakan lem super yang biasa digunakan untuk mengelem akrilik maupun kaca akuarium, dalam hal ini lem yang dibutuhkan 2 botol lem dengan berat 1 botolnya yaitu 250 gram.

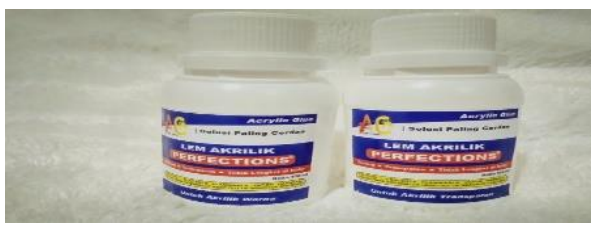

Gambar 6. Lem Super

\section{Dual Input Voltage}

Dual Input Voltage digunakan untuk merubah arus tegangan AC menjadi arus tegangan DC.

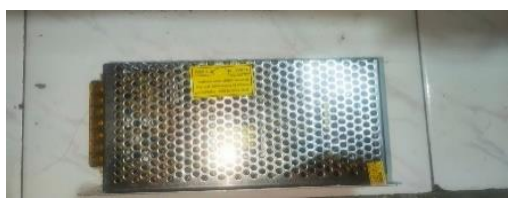

Gambar 7. Dual Input Voltage

\section{Solenoid Valve}

Solenoid Valve adalah katup yang digerakan oleh energi listrik, mempunyai koil sebagai penggeraknya yang berfungsi untuk menggerakkan piston yang dapat digerakan oleh arus AC maupun DC.

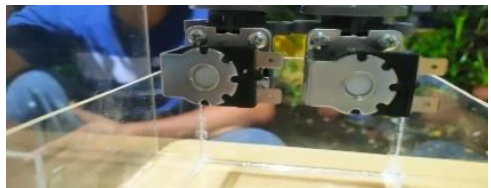

\section{Gambar 8. Solenoid Valve}

\section{Manometer}

Manometer adalah alat yang berfungsi untuk mengukur takanan udara dalam ruangan tertutup. Manometer dipasang disetiap tabung untuk mengetahui tekanan yang dihasilkan ketika alat dioprasikan.

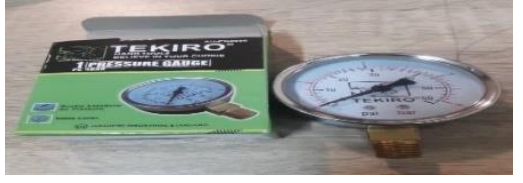

Gambar 9. Manometer

\section{Stop Kran}

Stop kran adalah suatu alat yang berfungsi sebagai valve penutup aliran yang sewaktu dilakukan perbaikan pada aliran dapat ditahan terebih dahulu.

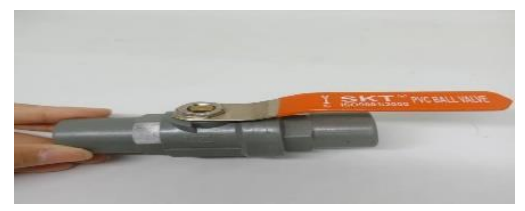

Gambar 10. Stop Kran

\section{Perancangan Sistem Oily Water Separator Berbasis Arduino.}

Manfaat dari alat peraga Oiy Water Separator adalah untuk penanganan Air yang berasal dari Bilges dimana Air tersebut masih bercampur dengan Minyak dan harus dipisahkan sebelum di buang ke Laut/Over Board.

\section{Pembahasan}

\section{Kelebihan dan Kekurangan}

Kelebihan dari alat ini adalah komponen mudah dicari. Karena dasar rancangan elektroniknya menggunakan sistem arduino dan untuk menghubungankan antar komponen menggunakan kabel maka lebih mudah untuk dibongkar pasang, 
mempermudah perbaikan jika terdapat kekeliruan skema atau penggantian komponen yang rusak maupun bongkar pasang untuk keperluan belajar.

Kekurangan alat peraga model pengembangan ini adalah jika terjadi kerusakan pada komponen walaupun hanya satu komponen dapat menyebabkan kegagalan sistem. Berikutnya adalah jika terjadi kesalahan pemprograman mikrokontroler dapat menyebabkan disfungsi komponen yang digunakan. Penggunaan filter pada alat peraga ini sangatlah kurang efisian atau termasuk boros, dikarenakan mudah kotor akibat proses utamanya yaitu penyaringan pada air.

\section{KESIMPULAN}

Dari hasil penelitian dan pembahasan yang telah diuraikan oleh penulis pada karya tulis ilmiah, maka dapat diambil kesimpulan sebagai berikut:

Pada proses perakitan harus dilakukan dengan teliti dan perhitungan penempatan komponen dengan tepat sesuai dengan sketsa/gambar rancang bangun yang telah direncanakan sehingga hasil pada pengoperasian oily water separator sesuai yang diharapkan.Perancangan elektronika lebih sederhana dengan menggunakan kontrol arduino dengan modul relay 2 channel untuk menggerakkan selenoid valve yang sebelumnya hasil ppm dibaca oleh sensor ppm untuk mengetahui dimana antara air dan oli ditempatkan

Bahan antara lain yaitu akrilik, pipa peralon, kran, manometer gauge, water level yang digunakan dalam membuat dan proses pembuatan bagian alat peraga dengan proses pembuatan secara manual baik menggunakan gergaji sebagai pemotong bahan ,bor sebagai pelubang bahan ,dan gerinda sebagai penghalus bagian alat peraga. Pengujian alat peraga menggunakan motor dc 12volt dapat menggerakkan sistem pada rancang bangun alat peraga oily water separator.

Saran
Berdasarkan kesimpulan yang telah diuraikan diatas, beberapa saran yang dapat disampaikan peneliti dalam menyelesaikan pembuatan rancang bangun alat peraga oily water separator adalah sebagai berikut: Desain pembuatan komponen alat peraga lebih mudah jika menggunakan autocad karena desain dapat terlihat dan presisi dalam pengerjaan pembuatan tidak terjadi kekeliruan saat menentukan posisi senter dari alat yang akan dibuat.Untuk menghasilkan karya yang sesuai dengan harapan dibutuhkan kesabaran dan ketelitian dalam pembuatan dan perancangan alat peraga model sistem oily water separator, baik dalam perancangan mekanik, elektronika, dan perancangan sistem kerjanya.

Mengingat rancangan alat peraga ini banyak menggunakkan bahan akrilik, peralon, dan komponen elektronika sebaiknya alat peraga diberikan cover agar terlindung dari debu pada saat disimpan.Pengembangan rancang bangun alat peraga oily water separator dapat dikembangkan dengan menambah proyek perhitungan ppm air dengan menggunakan pengukur ppm sebagai alat ukur sensor ppm sebagai tolak ukur agar dapat mengetahui kadar ppm air yang akan dibuang ke laut.

Bagi Taruna dan Taruni Politeknik Ilmu Pelayaran Semarang serta peserta diklat, agar alat peraga model sistem transmisi penggerak utama kapal dapat digunakan sebagai alat untuk media belajar ilmu mesin penggerak utama kapal (MPU) sebagai dasar pengetahuan sistem oily water separator khususnya pesawat bantu yang ada dikapal. Penulis mengharapkan agar hasil karya dari penyusunan skripsi ini dapat dijadikan referensi

\section{DAFTAR PUSTAKA}

Arsyad, Azhar, 2013, Media Pembelajaran Edisi Revisi. Rajawali, Jakarta.

Annisah, Siti, 2014, Alat Peraga Pembelajaran Matematika. Jurnal Tarbawiyah. Volume: 10 No. 1. 
Husein, Umar, 2011, Metode Penelitian Untuk Skripsi. Raja Grafindo, Jakarta.

Kris H Timotius, 2017, Pengantar Metodologi Penelitian. ANDI, Yogyakarta.

O’Brien dan Marakas, 2010, Management System Information. McGraw Hill, New York.

Cegielski, Prince, 2013, Prototype. Rainer.USA.

Sasakura Engineering Co., LTD, 2014, Fresh Water Generator. Osaka, Japan.

Suharjana, Agus, 2010, Evaluasi Pembelajaran, Surakarta.

Tim Penyusun Pesawat Bantu Politeknik Ilmu

Pelayaran Semarang, 2003, Oily Water Separator. Semarang.

Prof. Dr. H. M. Rudy Sumiharsono, Mm. Dan Hisbiyatul, S.Ag.M.Pd., 2018, Media Pembelajaran, (CV Pustaka Abadi, 2018), hlm. 9. Jember 